Throughout this paper the density of the water is given as reduced to $15^{\circ} 56 \mathrm{C}$. $\left(60^{\circ} \mathrm{F}\right.$.). It is specific gravity at $15^{\circ} .56$ referred to pure water at $4^{\circ} \mathrm{C}$. as unity.

The water-sampling stations and the principal contour lines of depth are shown in the chart of the Firth of Forth (Fig. I).

\section{THE PEARL FISHERIES OF TAHITI}

A RECENT issue of the Fournal Officicl contains a lengthy report by M. Bouchon-Brandely, Secretary of the College of France, who was sent by the Ministry of Marine and the Colonies on a mission to Tahiti to stuly questions relating to oyster-culture there. The principal product of what M. Brandely, with "the summer isles of Eden" fresh in his mind, calls " notre belle et si poétique colonie de Tä̈ti" is mother-ofpearl. All its trade is due solely to this article, which for a century has regularly attracted vessels to the islands which compose the archipelagoes of Tuamotu, Gambier, and Tubuai. The mother of-pearl which is employed in industry, and especially in French industry, is furnished by various kinds of shells, the most estimated, variegated, and beautiful of which are those of the pearl oyster. There are two kinds of pearl oystersone, known under the name of pintadine (Meleagrina margaretifera), is found in China, India, the Red Siea, the Comoro islands, North-Eastern Australia, the Gulf of Mexico, and especially in the Tuamotu and Gambier archipelagoes; the other, more commonly called the pearl oyster (Meleagrina radiata), comes from India, the China seas, the Antilles, the Red Sea, and Northern Australia. The shell of the former is harder, more tinted, more transparent, and reaches greater dimensions than the latter. Some have been found which have measured thirty centimetres in diameter and weighed more than ten kilogrammes, while the Meleagrina radiata rarely exceeds ten centimetres at the most, and never weighs as much as $\mathrm{I} 50$ grammes. Both varieties supply pearls, those of one kind being at one time more favoured, at another time those of the other. This depends on fashion ; but, on the whole, those found in the great pintadine are more beautiful, and the colour more transparent, than those of its congener. The amount of the trade from Tahiti in pearls cannot be stated with accuracy, as there is much clandestine traffic, but $M$. Brandely puts it down approximately at 300,000 francs, England, Germany, and the United States being the chief markets for the fine pearls. The great pintadine is found in great abundance in the Tuamotu and Gambier islands. The siluation there is very favourable to them ; in the clear and limpid waters of the lagoons they have full freedom for development, and are undisturbed by storms. Mother-of-pearl is found in almost every one of the eighty islands which form the archipelagoes Tuamotu and Gambier. These belong to France, having been annexed at the same time as Tahiti and Moorea, and have a population of about 5000 people, all belonging to the Maori race. M. Brandely gives an interesting description of these little-known illands and people. The latter appear to hover always on the brink of starvation, as the islands, which are composed mainly of coral-sand, produce hardly anything of a vegetable nature. While the neighbouring Society islanders have everything without labour and in abundance, the unfortunate inhabitant of Tuamotu is forced to support existence with cocoa-nuts, almost the only fruit-trees which will grow on the sandy beach, with fish and shell-fish which are poisonous for several months of the year, and often they have to kill their dogs for want of other animal food. There are no birds, except the usual sca-birds; no quadrupeds, except those brought by man; no food resources necessary to European life, except what is brought by ships. Although the people are gentle and hospitable, they practise cannibalism, and $M$. Brandely suggests that it is pitiless hunger alone which has driven them into this horrible custom. These miserable people are the chief pearl-divers of the Pacific ; indeed it is their only industry, and women and even children take part in it. There is at Anaa, says the writer, a woman who will go down twenty-five fathoms, and remain under water for three minutes. Nor was she an exception. The dangers of the work are great, for the depths of the lagoons are infested by sharks, against which the divers, being unable to escape, are forced to wage battle, in which life is the stake. No year passes without some disaster from sharks, and when one happens all the divers are seized with terror, and the fishing is stopped for a time. But gradually the imperious wants of life drive them back to the sea again, for mother-of-pearl is the current coin of the Tuamotu. With it he buys the rags which cover him, the little bread and flour which complete his food, and alcohol, "that fatal present of civilisation," for which he exhibits a pronounced passion. 'Twenty or thirty years ago the trade in mother-of-pearl in the Tuamotu archipelago was very profitable for those engaged in it. For a valueless piece of cloth, a few handfuls of flour, or some rum, the trader got half a ton of mother-of-pearl worth one or two thousand francs, or even fine pearls of which the natives did not know the value. The archipelagoes were frequented by vessels of all nationalities; mother-of-pearl was abundant, and pearls were less rare than they are now. The number of trading-ships increased; there was competition amongst them, and consequently a higher price to the natives, who fished to meet the new demand with improvident ardour. The consequence is that the lagoons are less productive, and that even the most fertile give manifest signs of exhaustion. The prospect of having the inhabitants of Tuamotu thrown on its hands in a state of helpless destitution, as well as of the disappearance of the principal article of the trade of Tahiti, and an important source of revenue to the colony, alarmed the Colonial adiministration, and the Ministry of Marine and the Colonies in Paris. Accordingly, M. Brandely was selected to study the whole subject on the spot. The points to which he was instructed to direct especial attention were these: (I) The actual state of the lagoons which produce oysters; are they beginning to be impoverished, and if so what is the cause, and what the remedy? (2) Would it be possible to create at Tuamotu, Gambier, Tahiti, and Moorea, for the cultivation of mother-of-pearl, an industry analogous to that existing in France for edible oysters? Would it be possible by this means to supply the natives of Tuamotu with continuous, fixed, remunerative labour which would render them independent, and remove them from the shameless cupidity of the traders? Could they not be spared the hardships and dangers resulting from the continued practice of diving, and be turned to more fixed sedentary modes of life, by which they might be raised gradually in the social scale? (3) Should the pearl fishing in the archipelagoes be regulated, and, if so, what should be the bases of such regulations? It was on the mixed economical and philanthropic mission here indicated that M. Brandely went to Tahiti in February last. The statistics did not show any decline in the production of mother-of-pearl, but a careful study on the spot showed that this was due to the great amount of the clandestine traffic, and that the lagoons were growing less productive day by day, that beautiful mother-of-pearl was becoming rarer, and in order now a-days to get oysters of a marketable size, the divers are forced to go to ever greater depths. M. Brandely recommends prompt and vigorous measures be taken at once, as the lagoons of 'Tuamotu will soon be ruined for ever. The partial steps already adopted have becn useless. The total prohibition of fishing in some of the islands for several years has failed, because it has been found that the pintadine is hermaphrodite, and not, as formerly was believed, unisexual. The cause of the impoverishment of the lagoons is excessive fishing, and nothing else. $\mathrm{He}$ thinks that it is possible to create in Tuamotu, Gambier, Tahiti, and Moorea a rational and methodical cultivation of mother-of-pearl oysters, analogous to that existing with regard to edible oysters on the French coasts, and to constitute for the profit of the colony an industrial monopoly which no other country can dispute, for nowhere else can such favourable conditions be met with.

\section{SOCIETIES AND ACADEMIES LONDON}

Royal Society, March 26.- "On the Peculiar B.haviour of Glow Lamps when raised to High Incandescence." By W. H. Preece, F.R.S.

The experiments described had for their object the investigation of a phenomeion observed by Mr. Edison, who brought it to the author's notice last autumn. Between the limbs of an incandescent filament of a glow-lamp a thin, narrow platinum plate being fixcd with an independent wire connection, and a sensitive galvanometer being placed in circuit between the filament and the platinum, a derived current is observed to pass through the galvanometer and through the rarefied space at the bottom of the $\operatorname{limb}$ when the main current is increased to a certain strength and the filament reaches a certain degree of incandescence, the strength of the derived current increasing with the increased brilliancy of the glowing filament. In the author's investigations Mr. Edison had made other lamps, in 
which the centre conducting plate was of copper, iron, and carbon respectivcly; but the general effects were practically the same as when platinum was uscd. The currents (from FaureSellon-Volclemar rells) were increased gradually, the effects of each increase being carcfully noted. The nature and resistance of the rarified space in the shunt-circuit had to be ascertained Certain increments in the current were followed by a diffused blue effect in the globe, more or less intense, accompanied in each instance by a marked fall in the resistance of the shintpointing to an intimate connection between the two phenomena, The strength of the shunt-current when the faint blus tinge appearcd was: with carbon, 3.42 ; with iron, 3.85 ; and with copper, 3.80 milliamperes. No perceptible difference in the results was observable with lamps in which the centre plate was a fine wire or a very broad surface, nor when the plates were doubled. That the effect was due primarily to the "Crooke's bombardment," or the projection of molecules in right lines from the carbon filament on to the metal plate was confirmed by the following experiments :-Lamps were constructed varying the position of the platc. In one the plate, was fixed at the end of a tube having a portion of the filament exposcd to the plate; in this case, with an E.M.F. of 108 volts in the main circuit, the blue effect entered the tube. In another lamp the tube was so constructed that no portion of the filament was opposed by right lines to the motal phate; with II 2 volts the blue in the globe became very marked; with $\mathbf{I} 20$ volts the bulb was hot, the tube cool. Another lamp was constructed with three branches at right angles to each other, and each metal plate taken in succession; no result was obtained, no current being evident in either section. $\Lambda l$ the expcriments went to show that, when once the bluc effect appeared, destruction was only a question of time. Hence this bluc effect is an indication of the advent of disintegration, and a very useful warning of danger ahead. Whenever the incandescence of the filament is raised beyond a certain limit, the interior of the glass envelope is blackened by a layer of carbon which has been deposited by a Crooke's bombardment effect.

It was evident from the observations that the Erlison effect is due to the formation of an arc between the carbon filament and the metal plate fixed in the vacuous bulb, and that this arc is due to the projection of the carbon particle in right lines across the vacuous space. Its presence is detrimental to the life of the lamp, and as its appearance is contemporaneous with the blue effect, the latter is a warning of the approach of a critical point and a sure indication that the E.M.F. is dangerously high. It is also clear that, as the Edison effect is only evident when we are "among the breakers" it is not available for practically regulating the conditions of electric light currents as its ingenious discoverer originally proposed.

Mathematical Society, April 2.-J. W. L. Glaisher, F.R.S., President, in the chair.-Dr. R. Stawell Ball, F.R.S., Astronomer Royal, Ireland, and Baboo Bast, of Bhowanipore, were elected Members. - The following communications were made :-New relations between bipartite functions and determinants, with a proof of Cayley's theorem in matrices, by Dr. T Muir-On eliminants, and associated roots, by E. B. Elliott. -On five properties of certain solutions of a differential cquation of the second order, by Dr. Routh, F.R.S.-On the argi ments of points on a surface, by R. A. Roberts.-On congruences of the third order and class, by Dr, Hirst, F.R.S.

Geological Society, March Ir.-Prof, T: G. Bonncy, T).Sc., T.L.D., 1...S., President, in the chair.-William Tester and Thomas Stewart were elected f ellows of the Society. - The following communications were read:- The granitic and schistose rocks of Donegal and some other parts of Ircland, by C Callaway, D.Sic, F.G.S. The author first recalled attention to the current theorics on the nature of the Donegal granitic rock, one which described it as a Jighly metamorphosed portion of a sedimentary series, another which regarded it as a mass of Laurentian gnciss. In his view, however, it was a true igneous granite, posterior in age to the associated schists. In six dis tricts examined it was intrusive and sent out veins. The apparent interstratification with bedded rocks was explained as a series of comparatively regular intrusions. Where the granite was seen in contact with limestone, the latter contained garnets and other accessory minerals. No gradation could be discovered between the granite and any other rock, the junctions (even in the case of small fragments of schist immersed in granite) being well marked. The granite was distinctly foliated. In some localities there was mereiy a linear arrangement of the mica; but ncar the western margin of the granite promontory there was a striping of light and dark bands, the colour of the latter being due to the abundance of black mica. The gneissic structurc was attributed to lateral pressure, the existence of which in the associated strala was seen in the conversion of grits into schist-liko rocks, in the production of cleavage in beds of coarse materials, in the crushed condition of some masses, in the overthrow of folds, and in the production of planes of thrust. The direction of the pressure was perpendicular to the planes of foliation in the granite. The schistose rocks of the region were divided into two groups. The Lough Fuyle series consisted of quartzits, quartzose grits with a mineralised matrix, slaty-looking schists, fine-grained satiny schists, black phyllites, and crystalline limestones and dolowites. The semicrystalline condition of most of these rocks was characteristic. This series was well scen at Londonderry and on Lough Foyle, and formed a broad band striking to the south-west. These rocks were compared with similar types in the Hill of Howth (north of Dublin), near Aughrim (Co. Wicklow), and south of Wexford. The Leinster semicrystalline masses were quite unlike the Wicklow Cambrians, and bore a strong resemblance to the slaty series of Anglesey. They wor lithologically intermediate between the Doncgal and Anglesey groups, and from a comparison of all these areas the author referred the Longh Foyle series, with some confidence, to the Pebiclian system, The prolongation of the Lough Foyle rocks into the Grampian region was well known, and Ireland thus served to connect some parts of the Scottish highlands with South Britain. The author was not prepared to correlate this Donegal series with any American group, but the lithological affinities were rather with the Taconian that with the ITuronian. The Kilmacrenon series, in which the granite is intrusive, was described as crystalline, and older than the Lough Foyle group. It was mainly made up of micaceous, quartzose, homblendic, and hydromagnesian schists, quartzites, and crystalline limestones. There were no indications in these rocks of a metamorphism progressive in the direction of the granite. This series was lithologically similar to the Montaiban system. Fifty-five microscojic slides of Donegal and Leinster rocks had been examined by Prof. Bonney, whose observations confirmer those of the author both as regards the nature and relations of the granite and the general characters and state of crystallisation of the two schistose groups.-On hollow spherulites and their occurrence in ancient British lavas, by Grenville A. J. Cole, F.G.S.

\section{EDINBURGH}

Royal Society, March 2.-Robert Grey, Vice-President, in the chair. $\rightarrow$ At the request of the Society's Council, Dr. $\Lambda$. Geikie, Director-General of the Geological Survey, gave an address on the recent progress of the Survey. He indicated what would be the future work of the Survey.

March I6.--Thomas Stevenson, M.I.C.L., President, in the chair. - Prof. Tait called attention to anticipations of the kinetic theory, and of synchronism, which occur in a tract, "De Potentia Restitutivâ," published by Hooke in 1678. - Prof. Crum Lrown read a paper on the hexagonal system in crystallography. The forms of the uniaxial systems may be regarded a: derived from forms or parts of forms or combinations of the rcgular system by uniform expansion or contraction in a direction parallel to the axis of the uniaxial system, i.e. normal to a face of the cube for the tetragonal, and normal to a face of the octahedron for the hexagonal system. Faces, thereforc, which are, in the regular form or combination, at right angles to or parallel to such axis, retain their relative angular position un. changed in the uniaxial form or combination, and can be represented by means of indices referring to the rectangular axes of the regular system, whatever be the amount of the deforma. tion (expansion or contraction). These faces are prism faces, parallel to the axis, and basal faces at right angles to it. All other faces have their angular position affected by the deformation. These other faces are pyramid faces. Lach pyramid face lies between, and in the same zone with, a prism face and a basal face. It may, therefore, be represented by the symbol $a s+\frac{I}{p} b t$, where $s$ and $t$ are the symbols of the prism face and the basal face respectively, $a$ and $b$ are small whole numbers, and $\rho$ is the ratio of the length of a line parallel to the axis after, to the length of the line before deformation. We may put $\frac{b}{-}=n$, 
when this becomes, for the tetragonal $\operatorname{system}(k \geqslant 0)+\frac{\mathrm{I}}{\rho} n$ (OOI), which is $\left(h k \frac{n}{\rho}\right)$ the Miller symbol for a pyramid face in this system, with the ratio of the parameter of $z$ to that of $x$ or $y$, expressed by $\rho$. In the hexagonal system the symbol $s+\frac{\mathrm{I}}{\rho} n t$ takes the form $(h k l)+\frac{1}{\rho} n(I I I)$, where $h+k+l=0$. We may leave $\rho$ understood, as it is constant for the same substance and same temperature, and write this in the contracted forms $(h k l, n)$. This gives $h+\frac{n}{\rho}, k+\frac{n}{\rho}, l+\frac{n}{\rho}$, as the coeflicients of $x, y$, and $z$ in the equation of the face referred to the rectangular axes of the regular system. These axes are, of course, not crystallographic axes of the hexagonal system, but some advantages arise from their use. They are rectangular, and therefore the ordinary formula of solid geometry can be used; the symbol of the general form $(h k l, n)$, where $h k$ and $l$ are free to change places and change sign together, and $n$ changes sign independently, gives a clear oversight of all the faces of the holohedral form, and enables us to derive from the symbol the various kiuds of hemihedry.-In a note on the effect of temperature on the compressibility of water, Prof. Tait showed that the minimum compressibility temperature of water appears to rise with increase of pressure.-Dr. A. B. Griffiths' paper on chemicophysiological investigations on the cephalopod liver and its identity as a true pancreas, was read by Mr. Hoyle.

\section{PARIS}

Academy of Sciences, March 3o.-M. Bouley, President, in the chair.-Experiments connected with the phenomena occurring within the sphere of organic life during epileptic fits, by M. Vulpian. The effects of epileptic attacks artificially prodiced on the dog were found to agree substantially with those observed in human patients subject to ordinary affections of this class. - A reply to the remarks of $M$. Troost on the objections advanced against his experiments with the hydrate of chloral, by M. Friedel.-Provisional elements of Borrelly's new planet 246 , determined at Toulouse from observations taken at Marseilles and Berlin, by M. Andoyer.--Observations of the same planet made at the Paris Observatory (equatorial of the West Tower), by M. G. Bigourdan.-Latitudinal distribution of the solar phenomena (spots, faculæ, eruptions, and protuberances) observed during the year 1884 , by M. P. Tacchini. From the observations here tabulated the author concludes that last vear the phenomena were more numerous in the southern hemisphere of the sun, where protuberances occurred frequently even near the pole. The spots, facula, and eruptions were numerous, especially in a wide zone stretching north and south of the equator, whereas in preceding years a notable diminution had been observed close to the equator itself.-A geometrical presentation of the three constants relative to the great mirror $M$ of the sextant, by M. Gruey.-A method of measuring the double stars by means of the spectroscope, by M. Ch. V. Zenger.-OOn an apparatus intended to regulate the curvature of the surfaces and the refraction of lenses (four illustrations), by M. L. Laurent. This apparatus is described as a focometer of great precision, generally applicable to all curved surfaces, in ordinary cases showing at a glance and without preparation the quality of any optical system.-Remarks on the actinometric observations made during the year 1884 at the Observatory of the Montpellier School of Agriculture, by M. $\Lambda$. Crova.--Heat of combustion of the Ronchamp coal, by $M$. Scheurer-Kestrer.-On the formation of the hydrocarbonate of magnesia (hydromagnesite), i) M. R. Engel. In this paper the author gives the results of experiments made for the purpose of determining the causes of the formation of hydromagnesite in the precipitation of a soluble salt of magnesia by alkaline carbonates.-Experiments on the reduction of mannite $\left(\mathrm{C}_{6} \mathrm{H}_{8}(\mathrm{OII})_{6}\right)$ by means of formic acid, by M. C. Friedel. - On the formation of the kreatines and kreatinines: a new kreatinine, $\alpha$-ethylamidopropionocyamidine, by $M$. I. Duvillier. - On the simultancous contractions of antagonistic muscles, by M. Beaunis.-On the pelagic fauna of the Baltic Sea and Gulf of Finland, by MM. G. Pouchet and J. de Guerne. From specimens of crustaceans (Cyclops quadricornis, Daphnclla brachyura, Daphnia quadrangula, \&c.) fished up last year in the Gulf of Finland, the authors conclude that the pelagic fauna of that slightly brackish sea resembles that of the great European lakes, while the central basin of the Baltic offers well. marlied transitional forms between fresh-water and marine animals. - On the existence of limestone at Fusulines in the Morvan geological arca, by M. Stan. Meunier.-On some crystals of celestine (sulphate of strontian) discovered near Grauchet (Tarn), by M. A. Caraven-Cachin.

\section{BERLIN}

Physiological Society, February 27.-Prof. Busch laid before the Society two preparations illustrative of his in vestigations into the laws of ossification. The one preparation was of the inferior maxilla of a dog, in which, when the animal was from three to four months old, two pairs of precisely similar grains of shot were inserted, as fixed marks, into holes bored by a gimlet of the same diameter. In order that such marks might be really fixed points from which the process of growth could be studied, it was necessary that the pieces of metal inserted into the osseous tissue should not project beyond the surface of the bone, nor, on the other hand, should they touch on other organs by the growth of which they would be liable to be displaced. In the inferior maxilla of a dog Prof. Busch had made four marks, two on each side, at distances of several centimetres, and then, with an exact pair of calipers, he measured the distances of the four grains of shot from each other. The wounds soon healed, the dog did not seem to suffer the least inconvenience, and after I 12 days was killed. The examination of the lower jaw now showed that of the four grains there were only three still remaining, the fourth not being discoverable. The two placed on one side of the lower jaw, in front and behind, showed exactly the same distance from each other as at the beginning of the experiment. The distance of one grain on one side from the corresponding grain on the other had on the other hand grown greater, while the length of the whole lower jaw from the posterior angle to the anterior end had throughout the period in question undergone an increase of about five centimetres. From these results Prof. Busch inferred that the increase in length of the lower maxilla was not due to interstitial growth but to apposition. The second preparation had for its object to ascertain facts regarding the growth of the epiphyses of the long bones whether it proceeded from the terminal line between epiphysis and diaphysis, from the epiphysal line, or from the articular cartilage. For this purpose steel pins, I centimetre long, were inserted into previously bored holes, one pin close under the epiphysal line of the tibia, a second in the epiphysis of the tibia, a third in the epiphysis of the femur, and a fourth close above the epiphysal line of the femur. The point of the gimlet was broken off during the operation, and served as a fifth mark. The question as to the mode by which the epiphyses grew was to be decided by the eventual change in the distance between mark 2 and mark 3. The experiment in this case likewise was carried out on a big dog of three months old, which was lilled II9 days after the operation. The examination of the marks then showed that mark I was removed several centimetres lower down, lying horizontally under the periosteum. Mark 2 lay apparently unchanged at its original spot; mark 3 was shifted a large piece upwards, and lay horizontally under the periosteum of the diaphysis. $\Lambda$ s a result of the operation, therefore, instead of under the epiphysal line, it was inserted above that line into the diaphysis; mark 4 was not to be found; mark 5, the broken-off gimlct-point, lay far up on the posterior edge of the diaphysis. As to the growth of the epiphysis, the experiment had therefore no significance, seeing that mark 3 was not inserted into the epiphysis of the femur. It showed, however, indispulably that the diaphyses grow by apposition from the epiphysal line, and that in proportion as the parts retired from this line, they became from resorption thinner and slenderer. In the discussion on this communication, Prof. Wolff stated that he had performed a great number of experiments on the lower jaws of quite young rabbits, which, contrary to the results obtained by Prof. Busch, clearly demonstrated the interstitial growth of the bone in qucstion. After he had quile concluded these experiments, he would lay the results before the Society.-Prof. Ehrlich made a communication on physiologically important results he had obtained from his investigations into the isusceptibility of the different tissues to colouring matters. If colouring solutions-in particular methylic blue-were injected into living animals and then, with the utmost expedition, particular tissues were examined, interesting reactions of the living tissue under the colouring materials would be perceived, which, in spite of their rapid evancscence, revealed important facts which by other methods were in part wholly unascertainable, in part to be ascertained only with difficulty. 
After the injection of methylic blue, Prof. Ehrlich found in the submucous tissue of the tongute very numerous fibres and fibrous reticula coloured intensely bine which sent processe; to the epi thelial formations, and it was casy to determine that these fibres were the axis cylinders of the sensory nerves. These blue-tinged axis cylinders were found very numerously in the gustatory cuplets, at the basis of which they formed a quitc narrow reticula nct work, whence, then, single fibres ending in knots proceedect anteriorly to the ciliated cells. Network of blue fibres were found very copiously and closely in the cornea. The iris likewise showed blue plexuses, particularly on the anterior side; on the posterior side only long cancellated reticula were observed. In the muscles, on the other hand, were found only detached blue fibres, the ending of which in the muscle fibre could not be established. The axis cylinders of the motory nerves were, according to this experiment, not coloured by mothylic blue dutring life; it was only the sensory nerves which reacted to the colotring matter. The vessels, arteries, capillaries, and veins wcre surnonded by blue plexuses. It could not, however, be decidcd whether the blue fibres proceeded to the smooth muscle cells. In the retina the nervous layer showed no blue colouring. In tha ganglion layer, on the other hand, cells richly charged with blue, and having numerous branching processcs, were found, which, too, were in communication with the processes of neighbouring cells. In the mixed nerve stems and in the roots of the nerves no blue fibres were found. The central ends, on the other hand, showed a decided methylic blue reaction, as did also the peripherical cnds of the sensory nerves. In the brain blue firres were found only rarely, but were very abundant in the medulla oblongata, while they racre wanting, again, in the spinal marrow, and from these results it appears that the colouring of living organs with methylic blue was a very important means towards observing the endings of sensory nerves in them. It must, however, be borne in mind, that the examination had to be prosecuted very rapidly after the colouring process, bccause, in living tissue, the colouring material got very quickly -in the course of a few minutes-lost by diffusion, and the colonring of the axis cylinders disappeared. - Dr. Pendat laid belore the Society several preparations sent by P'rof. Adamkiewicz, of Cracau, and gave an explanation of them. After colouring with saffranine, Prof. Adamliewicz found, in transverse sections of nerve fibres and cords of the spinal marrow within Schwann's sheaths, yellow to brown coloured crescents, which were sections of peculiar fusiform cells, and in the opinion of Prof. $\Lambda$ damkicwicz represented hitherto unknown parietal cells, lying within the norve fibres, distinguished by their saffranino reaction.

Meteorological Society, Mar h 3.-Dr. Hellmann spoke on the rainfall of Germany. Aftei a short reference to the rain-maps of Germany, hitherto published, which had been in some degree prepared from insufficient material and according to inadequate methods, he sct forth the points of view which had determined the arrangement of sixty new rainstations. By grouping and comparing the new annual observations with those of ncighbouring stations, which ranged over a long series of years, he was now in a position to draw it number of important conclusions. He was able to estalslish, for exanple, that the eastern part of North Germany, and, in particular, the right bank of the Oder, was not, as had hitherto been supposed, a dry district, at least not over its whole area, seeing that there were several stations within that section show ing moderate amounts of rain. It was further ascertained that the views formerly prevalent respecting the rainfall in mountainous regions were not correct, each mountain chain not having been considered scparately when inductions were made from tho data hitherto accumulated, in which other essential factors came to be mixed up with that of the elcvation and vitiated the result. In regard to the yearly distribution of rain, Dr. Heilmann's investigations showed that the great North German plain was embraced within the region of the summer rains; that the curve of rain-quantity and rain-frequency sank from January to April, reaching its minimum in that period, whence it rapidly rose to its maximum, which was attained in the summer months, and then sank slowly to its winter values. The maximum of rainfall in the furthest east occurred in June; immediately to the west in July; still more to the west in August; in Sleswick, 1uter still; and in Heligoland, not till November. A closer examination of the rain-curve in North Germany showed that it consisted of two maxima, with a depression of greater dryness occurring in July. A similar double maximum was likewise found in South Germany and in North-West
Germany. The first and greater rain maximum occurred with the recurrence of cold in June, and, altogether, the curve of temperaturc in North Germany showed a perfectly corresponding, inverse course with that of the rain-curve. The mountains of Germany-the Sudetic Mountains, the Taunus, the Hary, the Thuringian Forcat - which were all separately investigated in respect of their rainfall-showed an inverse course in the yearly rain-cirve as compared with that of the plain. In the mountains, the maximum of rainfall occurred in winter, whence the curve sank in spring, then rose to a small sccondary maximum in summer, sank thereafter, and finally rose to its year's maximum in winter. In respect of the absolute rain maxima the observations nitherto made showed that for Germany the month's maximum amounted to about $9^{\circ} 45$ inches, and that the greatest daily rainfall amounted for the plain to about $5^{\circ} \mathrm{I}$ inches, and for the mountains to from 7.88 to $9^{\prime} 45^{2}$ inches. The greatest $h$ ourly rainfall hitherto observed was 290 inches. Jr. Hellmann exhibitod a self-reşistering rain-gauge by Hottinger, and explained its construction.--Or. Kremser de scribed an ascent of the Schncekoppe made by him on January 3 and 4 , 1885, and sutmilted some metcorological observations taken by him on that occasion. On the height of the ridge he had clear sunshine over leatl, while the mountains under him lay enveloped in fog, the contour of which he was thus in a position to observe. In the Riesengrund, into which the sur shone clearly, he saw a huge pillar of fog, the upper end of which was curved into a whirling shape, resembling the column of smoke in an ascending air-current, as described in Herr Vettin's experiment (vide NATuRE, vol. xxxi. p. 284). On the Schneelsoppe he saw the brown-red ring around the sun in a state of remarkaile completeness. About $10^{\circ}$ around the sun was a brilliantly white space, which passed through yellow and yellow brown into the copper-coloured ring, $62^{\circ}$ broarl. At the point where it touched the horizon the two limbs showed different tints. Before sunrise the moon was densely surrounded by a violet halo, which extended to about as far as $18^{\circ}$ from the moon, and gradually passed into the darkbluc sky. The observer stationed on the Schneekoppe related that he likewise had often, for now nearly a year, seen the violet laalo around the moon. Lastly, it was to be stated that, like all other exposed objects, the telegraph poles were covercd with immense masses of hoar-frost, so that they showed a diameter reaching to $\mathrm{I} \mathrm{m}$., and the rain-ganges were also so heavily covered with the hoar-frost as to be practically useless.

\section{CONTENTS}

Tredgold's "Carpentry".

The Myriopods of
Our Book shelf :-

Turner's "Examples in IIeat and Electricity" . . . 526

Knox's "Differential Calculus for Beginners". . . 527

Letters to the Editor:-

Rock-Pictures in New Guinca.-Dr. Emil Metzger

Mr. Lowne on the Morpholugy of Insects' Eyes. Benjamln T. Lowne; George J. Romanes, F.R.S.

How Thought prescnts itself among the Phenomena of Nature.-Prof. G. Johnstone Stoney, F.R.S. Magnetic Disturbance, - G. M. Whipple . . .

The Samsams, - Prof, A. H, Keane

Meteor,-H. Sadler. . . . . . . . . . . 53

Stecl Guns . . . . . . . . . 530

On the Formation of Snow Crystals from Fog on

Ben Nevis. By R. T. Omond

Bird Architecture. By Charles Dixon . . . . . 532

The Institution of Naval Architects

The Eggs of Fishes. By Prof. McIntosh, LL,D., F.R.S.

Notes

Our Astronomical Column :-

Ancient Occultations of Aldebaran . . . . . . 539

Barnard's Comet . . . . . . . . . . 540

Astronomical Phenomena for the Week 1885 , April 12-18

Geographical Notes

On the Salinity of the Water in the Firth of Forth.

By Hugh Robert Mill, B.Sc., F.C.S. (Illustrated) The Pearl Fisheries of Tahiti

Societies and Academies . . . . . . . . . . .

\section{7}

529

530

30

530 